ISSN 1112-9867

http://www.jfas.info

\title{
PHYSICO-CHEMICAL ASSESSMENT OF POMACE EXHAUSTED AND APPRECIATION OF THEIR COMPOSTABILITY IN THE DELEGATION OF KALAA KEBIRA (TUNISIA)
}

\author{
Y. M'Sadak ${ }^{*}$, M. Makhlouf and S. El Amrouni
}

Department of the Genius of the Horticultural Systems and the Natural Environment, Higher Institute of Agronomy of Chott-Mariem (ISA-CM), University of Sousse, Tunisia

Received: 24 July 2015 / Accepted: 04 September 2015 / Published online 01 May 2016

\begin{abstract}
Olive pomace is the solid by-product obtained from the extraction of olive oil revealing serious environmental problems in all Mediterranean countries olive growing. Generally, that pomace can be valued, among others, as a source of organic matter (composting). In this perspective, we have addressed in this work to the quantitive and qualitative characterization (limited to certain physico-chemical parameters) of the solid by-product of olive oil extraction in the delegation of Kalaa Kebira (Sousse, Tunisia) while appreciating their compostability. The results showed that those olive residues are essentially dry, carbon-rich and CF, low in nitrogen. They can be used as compost by combining them with other available sources of plant originand/or animal such as manure of cattle, sheep or poultry (in varying proportions and responsible of the nature very heterogeneous and the variable quality) that can be applied to improve soil fertility and crop productivity.
\end{abstract}

Keywords: pomace exhausted; disponibility; qualitative characterization; co-composting; Tunisian Sahel.

Author Correspondence, e-mail: msadak.youssef@yahoo.fr doi: http://dx.doi.org/10.4314/jfas.v8i2.2 


\section{INTRODUCTION}

The manufacturing process of olive oil has undergone evolutionary changes. The traditional discontinuous pressing process was initially replaced by continuous centrifugation, using a three-phase system and later a two-phase system. Depending on the different olive oil production method, there are different kinds of wastes. The classic production of olive oil generates three phases and two wastes: olive oil (20\%), solid waste (30\%) and aqueous liquor (50\%). The solid waste (olive cake or "orujo") is a combination of olive skin, pulp and pits $[1,2]$, containing approximately $5-8 \%$ of residual oil [3] that can be economically recovered in the pomace oil industry through extraction with n-hexane [4]. Nowadays, the pomace exhausted is also considered as a cause of pollution for the environment [5]. Several studies have stated the negative effects of these forms of waste on soil's microbial populations, aquatic ecosystems [6] and even on the air [7], and signify one of the polluting by-products in the Mediterranean region [4]. Indeed, the solid olive biomass can be used in various fields, namely: Used for animal feed [8], a raw material for glycolpipids biosynthesis [9], residual oil extraction, energy recovery, soil amendment, the extraction of valuable polyphenols [10] and compost mixed with a support, coarse and nitrogen, generally referred to Co-composting. The process of composting olive pomace consists of mixing it with a blend of natural organic residues (e.g. olive leaves and twigs collected after cleaning the olive fruit in the mill, and/or straw, or manures), which is then allowed to decompose in aerated piles for 7 to 9 months. This means of re-utilization can help to improve soil fertility in olive oil farms which are characterized by low organic matter, reduce the cost of inorganic fertilisers or, for a commercial enterprise, can provide an additional source of revenue for the olive oil mill economy. The main reasons for composting are that Olive Mill Pomace (OMP) has a solid consistency which makes it difficult to manage, and to eliminate any phytotoxical effects by composting for at least 18 weeks.

In this context, the preliminary investigation is to evaluate these solid-products from the olive oil extraction on the quantity and quality in order to focus on their organic recovery by Co-composting in the delegation of Kalaa Kebira (Tunisian Sahel).

\section{EQUIPMENT AND METHODS}




\subsection{Characterization of pomace exhausted}

Crude olive cake obtaines by pressure contains crushed stones, skin, pulp, water $( \pm 25 \%)$ and a remaining quantity of oil (4.5 to 9\%) [11]. The extraction of pomace oil with n-hexane [4] allows the production of depleted pomace. Amino acid composition is similar to that of barely grain with a deficit in glutamic acid, proline and lysine [11]. The exhausted olive cake is a dry material (8 to $10 \%$ moisture) composed of ground olive stones and pulp. These form a dry material (8 to 10\% moisture), composed of fragments of olive stones and pulp. Such pomace, fine textured, rich in carbon and contains high amounts of lignin, cellulose and hemicellulose (easily biodegradable polymers).

\subsubsection{Quantitative characterization}

The quantities of pomace exhausted have been established by collecting data from the Regional Commissary for Agricultural Development (RCAD) of Sousse, particularly regarding quantities of olives produced, the number of oil mills divided into categories according to the extraction system and the capacity of trituration of each oil mill. To do this, an empirical formula for estimating quantities produced solid olive-products was applied as follows: Oil cake tons $=0.94 \times 0.3 \times$ Olives [12].

\subsubsection{Qualitative characterization}

To qualitatively characterize the pomace exhausted in the delegation of Kalaa Kebira, six samples (Picture 1) were collected from six oil mills distributed in the appropriate oil extraction system as follows.

- Traditional System: 2 oil mills, $\bullet$ Super Press: 2 oil mills, $\bullet$ Continuous system: 2 oil mills.

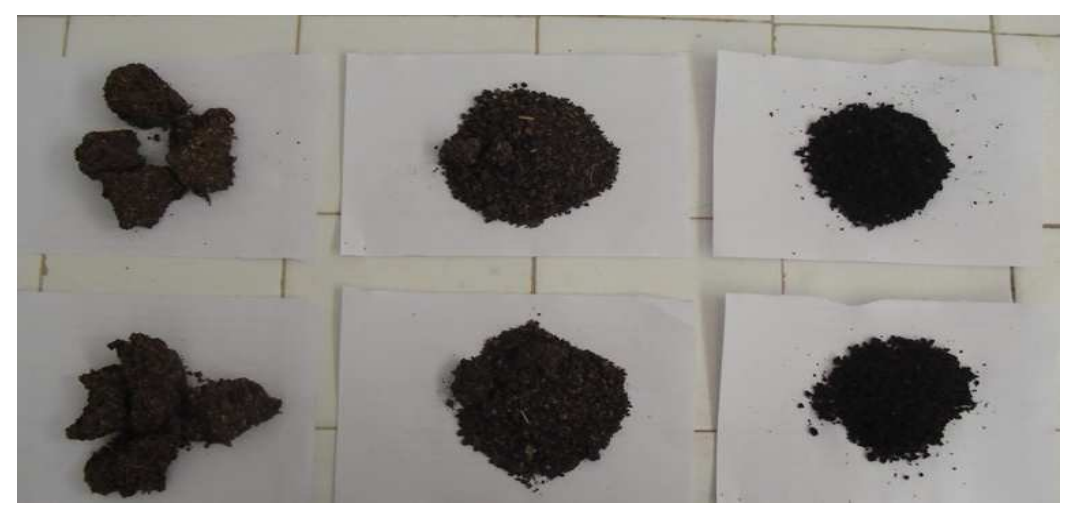

Picture 1. Samples of pomace exhausted analyzed 
Many chemical analyzes are needed to characterize the pomace exhausted. As an indication, include: $\mathrm{pH}$ measurements (using a pH meter), Dry Matter (DM) by drying in an oven, the electrical conductivity (EC) by conductimeter, the Organic matter (OM) by calcination in a furnace, Total Nitrogen (TN) by the method of Kjeldahl and the Crude Fibre (CF) by the method of Weende. These analyses were performed in the laboratory of Animal Production and Chemistry of the Higher Institute of Agronomic Sciences of Chott-Mariem (Sousse, Tunisia). Other parameters considered in this study were derived from the expressions recounted below. Salinity $(\mathrm{S})(\mathrm{g} / \mathrm{L})=0.7 \times \mathrm{EC}(\mathrm{mS} / \mathrm{cm})$

$\%$ Total Organic Carbon $(\mathrm{TOC})=\% \mathrm{MO} / 1.8$

Report Carbon/Nitrogen $(\mathrm{C} / \mathrm{N})=\mathrm{COT} / \mathrm{NT}$

$\%$ Total Nitrogenous Matter $(\mathrm{TNM})=\%$ NT x 6.25

\subsection{Composting of the pomace exhausted}

The potentially harmful substances in the pomace are biologically degraded during the process, allowing the safe use of the elaborated compost in agricultural fields. Although physical and chemical properties of olive pomace are rather unsuitable for composting (very low porosity, high moisture and low contents of $\mathrm{N}$ and $\mathrm{P}$ ), many complementary residues are usually generated in these areas, such as animal manures (source of $\mathrm{N}$ and P), olive leaves, cereal straw, almond shells or pruning wastes (bulking agents) [12]. Given the relative novelty of the extraction methodology, and probably because composting may not be the best management alternative for the very large amounts of pomace generated in the areas where oil production concentrates, there are not many studies published on composting of two phase olive mill residue. Together with different pile dimensions and aeration methodologies, a wide range of complementary residues have been evaluated: wheat straw [13], poplar sawdust and bark chips [14], cotton waste and maize straw [15], poultry manure [16], sheep litter [17], and cotton waste, grape marc, olive leaves and fresh cow manure [18]. The pomace concentration in the initial mixture ranged from $40.0 \%$ [17] to $94.6 \%$ [18]. Although the different experimental design make the results hardly comparable, all of them concur that compostability of olive mill pomace is achievable if adequate conditions and complementary residues are provided. The main objectives were to evaluate composting as a recycling solution to study the conditions 
leading to a fast and efficient process using simple and affordable equipment and methodologies, and to characterize the final product: Compost.

\section{RESULTS AND DISCUSSION}

\subsection{Characterization of solid waste}

\subsubsection{Quantitative characterization}

Based on annual estimates of the quantities of pomace produced from 2006 until 2011 in the delegation of Kalaa Kebira according to data provided to the RCAD Sousse (Table 1) and based on the formula reported by Trigui (2008) [12], we can deduce that the average annual quantity of recoverable pomace exhausted is 6093 tons.

Table 1. Estimated quantities of olive solid by products in Kalaa Kebira

\begin{tabular}{|l|c|c|c|c|c|c|}
\hline & $\mathbf{2 0 0 6 / 2 0 0 7}$ & $\mathbf{2 0 0 7 / 2 0 0 8}$ & $\mathbf{2 0 0 8 / 2 0 0 9}$ & $\mathbf{2 0 0 9 / 2 0 1 0}$ & $\mathbf{2 0 1 0 / 2 0 1 1}$ & Average \\
\hline Pomace (tons) & 6480 & 7125 & 6961 & 6751 & 2851 & 6093 \\
\hline
\end{tabular}

\subsubsection{Physico-chemical characterization}

The physicochemical characteristics vary across different pomace oil extraction systems (classic, press and continuous).

\section{Classical system}

Table 2. Qualitative Characterization of pomace exhausted by the classical system

\begin{tabular}{|c|c|c|c|c|c|}
\hline Parameters & Abbreviation & Unit & Oil mill 1 & Oil mill 2 & Average \\
\hline pH & $\mathrm{pH}$ & - & 6.08 & 5.98 & 6.03 \\
\hline Electrical Conductivity & $\mathrm{EC}$ & $(\mathrm{mS} / \mathrm{cm})$ & 0.58 & 0.80 & 0.69 \\
\hline Salinity & $\mathrm{S}$ & $(\mathrm{g} / \mathrm{L})$ & 0.40 & 0.56 & 0.48 \\
\hline Dry Matter & $\mathrm{DM}$ & $(\%)$ & 81.96 & 82.29 & 82.12 \\
\hline Organic Matter & $\mathrm{OM}$ & $(\%)$ & 94.89 & 96.13 & 95.51 \\
\hline Total Organic Carbon & $\mathrm{TOC}$ & $(\%)$ & 55.89 & 55.90 & 55.89 \\
\hline Total Nitrogen & $\mathrm{TN}$ & $(\%)$ & 1.16 & 1.07 & 1.11 \\
\hline Carbon-to-Nitrogen & $\mathrm{C} / \mathrm{N}$ & - & 48.73 & 53.15 & 50.94 \\
\hline Ratio & $\mathrm{TNM}$ & $(\%)$ & 7.23 & 6.70 & 6.96 \\
\hline Total Nitrogenous & & & & & \\
\hline
\end{tabular}




\begin{tabular}{|c|c|c|c|c|c|}
\hline Matter & & & & & \\
\hline Crude Fibre & CF & $(\%)$ & 36.87 & 40.40 & 38.63 \\
\hline
\end{tabular}

$58 \%$ of oil mills in the delegation of Kalaa Kebira use the traditional system with a crushing capacity of 486 tons of olives per day. The residue generated by this system are characterized by a $\mathrm{pH}$ value of 6.03 (Table 2), slightly acidic, very close to the lower limit announced (6-8), an EC of $0.69 \mathrm{mS} / \mathrm{cm}$ revealing a low salinity favorable to composting, low levels of total nitrogen $(1.11 \%)$, reflecting the difficulty of composting of this single substrate, but these solid residues can be recovered by Co-composting (composting sometimes called mixed or joint) combining a fermentable residue (rich in nitrogen). They are also characterized by a $\mathrm{C} / \mathrm{N}$ ratio of about 51 lower than the values given by Trigui [12] (57 to 60) and an average value CF (polymer essential to the nutrition of fungi and bacteria for the mesophilic and thermophilic phases composting) $38.63 \%$ confirming the composting difficulty of such a substrate.

\section{Super press system}

Table 3. Qualitative Characterization of pomace exhausted by the super press system

\begin{tabular}{|c|c|c|c|c|c|}
\hline Parameters & Abbreviation & Unit & Oil mill 1 & Oil mill 2 & Average \\
\hline pH & $\mathrm{pH}$ & - & 7.14 & 7.05 & 7.09 \\
\hline Electrical Conductivity & $\mathrm{EC}$ & $(\mathrm{mS} / \mathrm{cm})$ & 0.65 & 0.81 & 0.73 \\
\hline Salinity & S & $(\mathrm{g} / \mathrm{L})$ & 0.46 & 0.56 & 0.51 \\
\hline Dry Matter & $\mathrm{DM}$ & $(\%)$ & 80.95 & 76.81 & 78.88 \\
\hline Organic Matter & $\mathrm{OM}$ & $(\%)$ & 95.72 & 96.15 & 95.93 \\
\hline Total Organic Carbon & TOC & $(\%)$ & 54.29 & 55.13 & 54.71 \\
\hline Total Nitrogen & $\mathrm{TN}$ & $(\%)$ & 1.03 & 1.07 & 1.05 \\
\hline $\begin{array}{l}\text { Carbon-to-Nitrogen } \\
\text { Ratio }\end{array}$ & $\mathrm{C} / \mathrm{N}$ & - & 53.30 & 52.52 & 52.91 \\
\hline $\begin{array}{l}\text { Total Nitrogenous } \\
\text { Matter }\end{array}$ & TNM & $(\%)$ & 6.42 & 6.68 & 6.55 \\
\hline Crude Fibre & $\mathrm{CF}$ & $(\%)$ & 46.97 & 51.60 & 49.28 \\
\hline
\end{tabular}

Used by $22 \%$ of the oil mills in the delegation of Kalaa Kebira with a crushing capacity of 222 tons per day. It is found that the characteristics of residue from this system are similar to those 
found for the conventional system, except for $\mathrm{CF}$ which has a higher value than that observed for other systems (Table 3), confirming the difficulty biodegradability.

\section{Continuous system}

$20 \%$ of the oil mills in the delegation of Kalaa Kebira use this system with a crushing capacity 349 tons per day. No significant difference was detected for the characteristics of the treated residue identified (Table 4).

Table 4. Qualitative Characterization of pomace exhausted by the Continuous system

\begin{tabular}{|l|l|c|c|c|c|}
\hline Parameters & Abbreviation & Unit & Oil mill & Oil mill & Average \\
\hline pH & $\mathrm{pH}$ & - & 6.21 & 6.43 & 6.32 \\
\hline Electrical Conductivity & $\mathrm{EC}$ & $(\mathrm{mS} / \mathrm{cm})$ & 0.67 & 0.75 & 0.71 \\
\hline Salinity & $\mathrm{S}$ & $(\mathrm{g} / \mathrm{L})$ & 0.47 & 0.52 & 0.49 \\
\hline Dry Matter & $\mathrm{DM}$ & $(\%)$ & 83.87 & 82.31 & 83.09 \\
\hline Organic Matter & $\mathrm{OM}$ & $(\%)$ & 94.83 & 93.37 & 94.1 \\
\hline Total Organic Carbon & $\mathrm{TOC}$ & $(\%)$ & 55.17 & 55.65 & 55.41 \\
\hline Total Nitrogen & $\mathrm{TN}$ & $(\%)$ & 1.20 & 1.06 & 1.13 \\
\hline Carbon-to-Nitrogen & $\mathrm{C} / \mathrm{N}$ & - & 46.74 & 52.83 & 49.78 \\
\hline Ratio & & $(\%)$ & 7.49 & 6.61 & 7.05 \\
\hline Total Nitrogenous & $\mathrm{TNM}$ & $(\%)$ & 43.91 & 41.36 & 42.63 \\
\hline Matter & & $\mathrm{CF}$ & & & \\
\hline Crude Fibre & & & & & \\
\hline
\end{tabular}

The general results of analyzes related to the physicochemical characterization of pomace exhausted collected at different oil extraction systems in the delegation of Kalaa Kebira are given in Table 5.

- All the olive pomace is collected in the dry state, showing a relatively low humidity, varying between 16 and $23 \%$ with an average of $18.64 \%$.

- From the point of view $\mathrm{pH}$, proper development of bacteria and fungi responsible for the degradation of organic matter is provided for respectively adjacent $\mathrm{pH}$ to neutral (6-8) and 
slightly acidic [19]. According to the results found, we see that the $\mathrm{pH}$ of different samples of olive pomace analyzed is near to the standards (6-8), so favorable to life and microbial activity responsible for degradation the organic material during the composting process [20].

- Concerning the Electrical Conductivity (EC), we can say that is acceptable for all the samples studied. The recorded values show that all samples of all extraction systems have an electrical conductivity of about 0.69 to $0.73 \mathrm{mS} / \mathrm{cm}$.

- The measured salinity is relatively low with an average of $0.50 \mathrm{~g} / \mathrm{L}$. This salinity could be further reduced by leaching following irrigation with water that can be practiced during the composting process.

- The pomace is rich in Dry Matter (DM), with $95.18 \%$ on average, so it could be a good amendment for soils low in organic matter especially after composting.

- The pomace is also rich in Total Organic Carbon (TOC) with an average of $55.34 \%$ and CF with an average of $43.52 \%$.

- The $\mathrm{C} / \mathrm{N}$ ratio is too high, varying between 47 and 53, which exceeds the standards of fitness for composting of waste (30-35) which implies a degradation process of organic matter very slow and a long duration of composting. However, we can solve this problem by mixing the residue with other waste (wastes called green: olive tree leaves, twigs and small branches) which improve the aeration of compost windrows while decreasing the $\mathrm{C} / \mathrm{N}$ ratio by an additional supply of nitrogen (plant Homogenate fermentable costs).

- The high CF contents and also low total nitrogen contents varying between $1.03 \%$ and $1.20 \%$, identified at different samples of olive pomace composting confirmed the difficulty of the substrate. The CF is a polymer essential to the nutrition of fungi and bacteria in the mesophilic and thermophilic phases composting, opposite of lignin which proves its usefulness in more advanced stages of composting [21]), while nitrogen is needed to establish a nutritional balance of microorganisms [22].

- A high rate of organic matter can exceed $96 \%$, Based on the characteristics of the residue (dry biomass, fine and carbon) should be necessarily associate a wet biomass, coarse and nitrogen. Fresh vegetable mash, green leaves and bovine manure containing straw could be interesting waste for Co-composting of pomace. 
Finally, it should be noted that the TNM contents are insufficient (whatever the intended use: In the feed or composting) compared to what is announced by the DPV (2009) [23].

Based on the characteristics of the pomace exhausted (dry biomass, fine and carbon) should be necessarily associated to humid, coarse and nitrogenous biomass. As an indication, the ground material fresh plant, green leaves and bovine manure containing straw residues could be interesting for the Co-composting of pomace exhausted.

Table 5. General physico-chemical parameters of means exhausted pomace

\begin{tabular}{|c|c|c|c|c|c|}
\hline Parameters & Abbreviation & Unit & $\begin{array}{c}\text { Past } \\
\text { results }\end{array}$ & References & Raised average \\
\hline pH & $\mathrm{pH}$ & - & - & - & 6.48 \\
\hline Electrical Conductivity & $\mathrm{EC}$ & $(\mathrm{mS} / \mathrm{cm})$ & Max. 10 & $\begin{array}{c}\text { Iannotti and al. } \\
1994[24]\end{array}$ & 0.71 \\
\hline Salinity & $\mathrm{S}$ & $(g / L)$ & - & - & 0.49 \\
\hline Dry Matter & $\mathrm{DM}$ & $(\%)$ & 86 à 95 & Nefzaoui. 1985 & 81.36 \\
\hline Organic Matter & $\mathrm{OM}$ & $(\%)$ & - & - & 95.18 \\
\hline Total Organic Carbon & TOC & $(\%)$ & - & - & 55.33 \\
\hline Total Nitrogen & $\mathrm{TN}$ & $(\%)$ & & & 1.09 \\
\hline $\begin{array}{l}\text { Carbon-to-Nitrogen } \\
\text { Ratio }\end{array}$ & $\mathrm{C} / \mathrm{N}$ & - & 57 à 60 & Trigui. 2008 & 51.21 \\
\hline $\begin{array}{l}\text { Total Nitrogenous } \\
\text { Matter }\end{array}$ & TNM & $(\%)$ & 8 à 10 & DPV. 2009 & 6.85 \\
\hline Crude Fibre & $\mathrm{CF}$ & $(\%)$ & 35 à 50 & & 43.51 \\
\hline
\end{tabular}

\subsection{Compostable Resources and feasibility of Co-composting}

The composting is a controlled process, based on the control of the natural bioxidative process on organic substances transformed by aerobes microorganisms naturally present in the environment and in the matrixes, in a stabilized and sanitized organic substance, defined compost. Composting is one of the proposed solutions to enhance the solid effluents of the olive industry. It has been proven that composting of olive waste give good quality compost [25, 26]. 
Composting olive pomace enables it to be sanitized; the mass and volume of the product are reduced and stabilized prior to land spreading. As already mentioned, before composting, olive poamce is mixed with bulking agents such as olive tree leaves, which are gathered along with the olive fruit, twigs and small branches, straw, cotton waste and manure to increase the nutrient content, or any other materials of animal or plant origin which are available locally.

Today, there are no studies available on the characterization of currently marketed composts. Only one study has proposed commercial compost formed of seven samples collected from different oil mills located in several provinces of Andalusia (Spain). This compost is produced about $75 \%$ of olive pomace, $10 \%$ olive leaves, $12 \%$ sheep or poultry manure and straw $3 \%$ (Table 6). It's characterized by: $\mathrm{pH}$ (mean 8.03) was considered as optimal for the activity of microorganisms and plant growth [22, 27], Electric Conductivity was lower than the $10 \mathrm{mS} / \mathrm{cm}$, threshold established as indicator of possible phytotoxic/phyto-inhibitory effects on plants or in soil [24]. A high content of organic matter (60.5\%, on average) and carbon $(30.7 \%$, on average) (Table 6), a low organic matter degradation rate during composting has been reported [28].

Total nitrogen $(\mathrm{TN})$ averaged $1.5 \%$, and was higher for the compost which included relatively high amounts of manure during composting (Table 6). This value is within the range of that found for compost made from plant residues [29, 30] and similar to that reported for compost produced experimentally with pomace exhausted plus rabbit or sheep manure, and rice straw or almond shells [31]. The $\mathrm{C} / \mathrm{N}$ ratio ranged from 10.5 to 35.8 for the commercial compost, while such ratio is much lower for other experimental compost from the olive pomace (from 14.0 to 22.7) (Table 6), the total $\mathrm{K}$ (TK) in the composts averaged $1.7 \%$ and was highest for the compost, which included a high proportion of poultry manure and lowest for the compost, which included straw. These values were within the range of values reported by other authors $[28,32]$ for experimentally-produced compost and also similar to those of the only olive pomace [33]. This indicates that $\mathrm{K}$ was not lost through leaching during the composting process.

The total $\mathrm{P}$ of the composts averaged $0.41 \%$. TP values were lower than those of vegetable wastes and manures [34]. 
Polyphenol contents were less than $2 \%$, even though OMP is usually characterized by high levels of polyphenols. Polyphenols have been found to be toxic for some soil microorganisms [35], and this is one of the main reasons why direct application to soil cannot be recommended. The low polyphenol contents in the composts agree with values found by other researchers [36], who showed that the polyphenol content decreases during composting. In all cases, the polyphenol contents were lower than 4\%: the limit which has been established where there is a shift between net $\mathrm{N}$ mineralization and immobilization during decomposition [37]. Lignin and polyphenol contents of residues have been shown to be robust indices for the prediction of $\mathrm{N}$ mineralization from residue-N after incorporation in soil [38, 39] with typical thresholds for immediate net $\mathrm{N}$ mineralization being $<15 \%$ lignin and $<3-4 \%$ total extractable polyphenol contents [40, 41].

Table 6. Main physicochemical characteristics of compost olive pomace

\begin{tabular}{|l|c|c|}
\hline & $\begin{array}{c}\text { Compost commercially } \\
\text { produced (min- mean-max) }\end{array}$ & Other authors \\
\hline Organic matter $(\mathbf{g} / \mathbf{k g})$ & $272-605-879$ & $465-621$ \\
\hline Total C (g/kg) & $184-307-390$ & $301-491$ \\
\hline Total N (g/kg) & $10.7-15.0-20.0$ & $14.0-27.8$ \\
\hline C/N & $10.5-21.9-35.8$ & $14.0-22.7$ \\
\hline Total P & $0.19-0.41-1.19$ & $0.5-1.5$ \\
\hline Total K & $1.06-1.73-2.39$ & $20.6-39.5$ \\
\hline Lignin (g/kg) & $76.0-218-313$ & $410-426$ \\
\hline Polyphenols $(\%)$ & $0.94-1.33-2.1$ & - \\
\hline Labile organic C $(\mathbf{g} / \mathbf{k g})$ & $4.6-16.5-25.0$ & $7.3-10.2$ \\
\hline
\end{tabular}

${ }^{1}$ Other authors [28, 30, 31, 32, 42] for experimentally produced composts.

According to the qualitative characteristics of the samples studied of olive cake and by making recourse to the data from the study of commercial compost produced in Spain, we can recall that the pomace exhausted are dry, rich in carbon, fine-textured and difficult to biodegrade and can be used in composting, however, it should add another wet residue, nitrogenous and coarse texture (green leaves, ground material fresh plant, straw or sheep/cattle manure or poultry) 
playing the role of fermentable for improving the activity of the microbial flora, responsible for the degradation of OM. This addition creates a nutritionally balanced $\mathrm{C} / \mathrm{N}$ and adequate ventilation for the success of the fermentation process.

Such associations of those byproducts involve the Co-composting technique. The final product is olive co-compost (if the treated olive biomass is greater than or equal to 50\%). We can adopt the two mixtures below for the start of practice Olive Co-composting, by using irrigation based on olive mill wastes or liquid effluents.

Mixture 1: $50 \%$ pomace exhausted $+50 \%$ vegetable Homogenate

Mixture 2: $70 \%$ pomace exhausted $+30 \%$ cattle manure

\section{CONCLUSION}

The increase in oil production and the introduction of modern olive crushing techniques have placed the olive oil sector potential polluter position, a phenomenon that has grown with the advent of continuous systems in three phases. The olive pomace represents a solid waste biomass olive. However, such residues can be improved by aerobic biological valorization or composting. This study was able to unveil that the $\mathrm{pH}$ of various samples of pomace exhausted analyzed is close to the allowable lower limit, the EC is low fostering the fermentation mechanism, the $\mathrm{C} / \mathrm{N}$ ratio is too high, requiring the mixing of pomace with other residues able to improve the aeration of compost windrows, the average value of OM value is important. The CF is as high and total nitrogen is relatively low confirming the difficulty of composting for this the substrate alone.

Based on these various desirable characteristics in some cases (Organic Matter, Electrical Conductivity ...) and not recommended in other cases (Total Nitrogean, Carbon-to-Nitrogen Ratio and Crude Fibre), it should be said that these solid olive by-products have a good ability to Co-composting with other sources (wet, coarse and nitrogenous) of vegetable and/or animal. Such a processtending to develop strongly in recent years represents a natural way of aerobic biotreatment with many advantages. This allows biotreatment, indeed, reduce environmental risks associated with waste management, among others, by reducing their volumes and by the destruction of pathogens. 
In addition, it allows obtaining an organic amendment consisting of stable organic matter and humified containing nutrients.

The implementation of qualitative characterization should be as complete as possible for better aerobic biological valorization of the solid olive biomass. For further investigation, it should complement the physicochemical analyzes (especially phosphorus and potassium) and conduct biochemical analyzes (especially phenolic compounds, lignin).

\section{REFERENCES}

[1] Torrecilla J.S, Aragon J.M, Palancar M.C, European Journal of Lipid Science and Technology., 2006, 108, 913-924.

[2] Pinto F, Varela F.T, Gonçalves M, André R.N, Costa P., Mendes B, Fuel, 2014, 116, 84-93.

[3] Gögüs F, Maskan M, Journal of Food Engineering., 2006, 72, 378-382.

[4] Papaioannou E.H, Patsios S.I, Karabelas A.J, Philippopoulos N.A, Journal of Environmental Chemical Engineering., 2013, 1, 831-837.

[5] Baeta-Hall L, Sàágua M.C, Bartolomeu M.L, Anselmo A.M, Rosa M.F, Bioresource Technology., 2005, 96, 69-78.

[6] DellaGreca M, Monaco P, Pinto G, Pollio A, Previtera L, Temussi F, Bulletin of Environmental Contamination and Toxicology., 2001, 67, 352-359.

[7] Rana G, Rinaldi M, Introna M, Ecosystems and Environment., 2003, 96, 49-58.

[8] Haddadin M.S, Al-Natour R, Al-Qsous S, Robinson R.K, Bioresource Technology., 2002, $82,131-137$.

[9] Bednarski W, Adamczak M, Tomasik J, Plaszczyk M, BioresourceTechnology., 2004, 92, $15-18$.

[10] Roig A., Cayuela M.L, Sánchez-Monedero M.A, Waste Management., 2006, 26, 960-969. [11] Nefzaoui A, Valuation of lingo cellulosic residues in the diet of ruminants by treatmentwith alkali, Application to pomace oil. PhD Dr, Ing. Faculty of Science. Catholic University of Leuven., 1985, pp. 345.

[12] Trigui A, Consultation auprès du PNUD Tunisie, 2008, ANME (33/2008), Projet 00058135, pp. 121. 
[13] Canet R, Pomares F, Cabot B, Chaves C, Ferrer E, Ribo M, Albiach M.R, Science Direct., 2008 .

[14] Madejón E, Galli E, Tomati U, Agrochimica., 1998, 42, 135-145.

[15] Filippi C, Bedini S, Levi-Minzi R, Cardelli R, Saviozzi A, Sci. Util., 2002, 10, 63-71.

[16] Paredes C, Roig A, Bernal M.P, Sa'nchez-Monedero M.A, Cegarra J, Biol. Fert. Soils., $2000,32,222-227$.

[17] Hachicha R, Rigane H, Ben Khoder M, Nasri M, Medhioub K, Environ. Technology., 2003, 24, 59-67.

[18] Cayuela M.L, Bernal M.P, Roig A, Sci. Util., 2004, 12, 130-136.

[19] Cegarra J, Amor J.B, Gonza'1vez J, Bernal M, Roig A, Proceedings of the International Composting Symposium., 2000, 1, 19-23.

[20] Golueke C.G, Rodale Press., 1977.

[21] Godden B, Study of the composting process cattle manure, $\mathrm{PhD}$ in Agricultural Sciences, Free University of Brussels. Microbiology Laboratory., 1986, pp. 136.

[22] Mustin M, Le Compost : Gestion de la Matière Organique, Dubusc F. (Ed.), Paris., 1987, 117-263.

[23] Direction de la Production Végétale (DPV), Ministère de l'Agriculture, Rabat, Maroc., 2009.

[24] Iannotti D.A, Grebus M.E, Toth B.L, Madden L.V, Hoitink H.A.J, J. Environ. Qual., 1994, 23, 1177-1183.

[25] Mennane Z, Tada S, Aki I, Faid M, Hassani S, Salmaoui S, Physicochemical and microbiological characterization of the olive residue oil of 26 traditional mills in Beni Mellal, Laboratory Technologies., 2010, 5 (19), 4-9.

[26] Cadillon M, Lacassin J.C, Agricultural recycling of vegetable. Provence Canal Company and the Provence Region Development., 1991, pp. 10.

[27] Das K.C, Waste Manage., 2007, 28, 1785-1790.

[28] Alburquerque J.A, Gonzálvez J, García D, Cegarra J, Chemosphere., 2006, 64, 470-477.

[29] Sánchez-Monedero M.A, Roig A, Paredes C, Bernal M.P, Bioresource Technology., 2001, 78, 301-308. 
[30] Goyal S, Dhull S.K, Kapoor K.K, Bioresource Technology., 2005, 96 (14), 1584-1591.

[31] Alburquerque J.A, Gonzálvez J, García D, Cegarra J, Bioresource Technology., 2007, 98, 940-945.

[32] Hachicha S, Sellami F, Medhioub K, Hachicha R, Ammar E, Waste Manage., 2008, 28 (12), 2593-603.

[33] Alburquerque J.A, Gonzálvez J, García D, Cegarra J, Bioresource Technol., 2004, 91, 195-200.

[34] Pascual J.A, Ayuso M, García C, Hernández T, Waste Manage Res., 1997, 15, 103-112.

[35] Capasso R, Evidente A.A, Schivo L, Orru G, Marcialis M.A, Cristinzio G, J. Appl. Bacteriol., 1995, 79, 393-398.

[36] AitBaddi G, Alburquerque J.A, Gonzalvez J, Cegarra J, Hafidi M, Int. Biodeter. Biodegr., 2004, 54 (1), 39-44.

[37] Palm C.A, Gachengo C.N, Delve R.J, Cadisch G, Giller K.E, Agr. Ecosyst. Environ., $2001,83,27-42$.

[38] Fox R.H, Myers R.J.K, Vallis I, Plant Soil., 1990, 129, 251-259.

[39] Palm C.A, Sánchez P.A, Soil Biol. Biochem., 1991, 23, 83-88.

[40] Melillo J.M, Aber J.D, Muratore J.F, Ecology., 1982, 63, 621-626.

[41] Palm C.A, Rowland A.P, CAB International., 1997, 379-392.

[42] García-Gómez A, Roig A, Bernal M.P, Bioresource Technology., 2003, 86, 59-64.

\section{How to cite this article:}

M'Sadak Y, Makhlouf M and El Amrouni S. Physico-chemical assessment of pomace exhausted and appreciation of their compostability in the delegation of Kalaa Kebira (Tunisia). J. Fundam. Appl. Sci., 2016, 8(2), 208-222. 